\title{
EQUITABLE CLEAN-UP AND THE JURY: A SUGGESTED ORIENTATION
}

\author{
By A. Leo Levin $\dagger$
}

It is familiar law that a litigant in equity may ask and receive damages or other relief normally awarded in a court of law. The chancellor was not deterred from adjudicating such "legal" issues, for they were thought of as incidental and their disposition was necessary to the effective termination of the entire matter in dispute. ${ }^{1}$

Sound considerations of policy lay behind this "clean-up" rule, considerations which loom large and real against the background of two entirely independent systems of trial courts. The plaintiff entitled to both legal and equitable remedies needed relief from the burden of two days in court. Even worse was the plight of the litigant who had legitimately but vainly sought the chancellor's aid. The statute of limitations threatened him with total loss of remedy on an admittedly valid claim. ${ }^{2}$ It was the more dangerous a choice when crowded dockets and cumbersome procedure made the equitable process less than speedy. In any event, the dangers of a wrong choice of forum involved delay and all-consuming expense of litigation. ${ }^{3}$

Here then was plaintiff's dilemma: to turn first to law might, as a simple matter of res judicata, lose him the more-desired chancellor's remedy $;^{4}$ to turn to equity would often invite decision by an unpre-

$\dagger$ †.B., 1939, Yeshiva College; LL.B., 1942, University of Pennsylvania; Associate Professor of Law, University of Pennsylvania.

1. 1 Pomeroy, EQuiry Jurisprudence \$§ 181, 231 (5th ed., Symons, 1941); 1 Story, Commentaries on EqUiTy JuRisprudence \$ 64 (1836).

2. "It is unfortunate if, in prosecuting this claim in this Court, the Plaintiff has lost his remedy at law, but that cannot affect the decision of this case; . . . [Plaintiff], having sought compensation for damages in a Court which had not jurisdiction to award them, I think the decree of the Master of the Rolls, dismissing the bill, with costs . . . was correct; and I am under the necessity of now adding to such costs the costs of the appeal." The Lord Chancellor in Sainsbury v. Jones, 5 My. \& Cr. 1, 5, 41 Eng. Rep. 272, 273 (1839). See Stearns v. Beckham, 31 Gratt. 379, 426 (Va. 1879) ; Genet v. Howland, 45 Barb. 560, 572, 573 (N.Y. 1866). In the last case, decided under an early code, clean-up was held inappropriate, but the court chose to transfer the cause for jury trial rather than dismiss, emphasizing that a dismissal would have barred plaintiff from all recovery because of the running of the statute of limitations.

3. "Nine years after this cause had stood at issue as an equity cause, and when being finally heard, the defendants objected to the jurisdiction of a court of equity. . ." Waite v.' O'Neil, 76 Fed. 408, 411 (6th Cir. 1896). See also the reference to costs in note 2 supra.

4. Slaughter v. La Compagnie Francaises Des Cables Telegraphiques, 119 Fed. 588 (2d Cir. 1902), cert. devied, 191 U.S. 574 (1903). 5 Corrin, CoNTrACTS $\$ 1222$ (1951) ; 1 Chitry, Pleading * 243 (6th Am. ed. 1833). It has even been held that plaintiff is precluded from suing for specific performance if he had first sued for damages and voluntarily dismissed the action. Belding v. Whittington, 154 Ark: 561, 243 S.W. 808 (1922). Substantial authority contra is collected in 26 A.L.R. 111 (1923); 5 WiLliston, Contracts $\$ 1444$ A (Rev. ed. 1937). 
dictable conscience and perhaps the loss of all remedy. Equities had to be weighed on an imprecise balance and hardships measured by a rule the fine divisions of which were often known only to the chancellor himself. Small wonder then that the clean-up rule, the disposition of incidental questions legal in nature, was often applied even where all equitable relief was denied.

The cost of this efficiency was, however, substantial, for it involved the denial of trial by jury on all legal issues so adjudicated. In some situations this price was considered too heavy to pay for the trial convenience achieved. 5 . In others, where equity viewed a plaintiff's conduct as sufficiently reprehensible, the chancellor was pleased not to afford him aid by rapid disposition of a remaining issue. ${ }^{6}$

The clean-up rule thus emerges as a device to avoid procedural inequities inherent in a bi-partite judicial system which has since been abandoned. It was never available as an excuse for equitable jurisdiction in all suits initiated in equity, but on the contrary was strictly limited to certain categories of cases in which the advantages of applying it were deemed to outweigh the disadvantages. Our purpose is to examine the rule in the context of a substantially different legal system, one in which there are no longer separate courts of law and equity. At the outset we should consider briefly (1) the difference it makes today whether equity will clean-up or not; (2) the reason current cases include the backward look to examine clean-up as it used to be; (3) the extent to which modern procedures have eliminated the factors which, historically, gave rise to clean-up achieving the advantages without the disadvantages; (4) the extent to which new factors can support a contemporary clean-up rule.

Today, the right to a particular method of trial is the most significant single problem in this area. ${ }^{7}$ In its solution we are wont to use pigeonholes with double labels: "At Law-Jury Trial," "In Equity-

5. "I think it would be productive of very serious evil, if, in cases which are the proper subjects of an action for damages . . . a party could come here for a specific performance of it, or for damages; thus throwing upon a Court of Equity the functions which properly belong to a jury." Rogers v. Challis, 27 Beav. 175, 180, 54 Eng. Rep. 68,70 (1859).

6. Sée p. 342 infra.

7. In modern code practice "The only importance of knowing that it would formerly have been tried in equity is this: If it was triable in equity, then there will be no right to-day to have the damages tried by a jury." MCCormICK, Damages 69 (1935). The law-equity distinction may also give rise to problems of appellate review, statute of limitations, parties, enforcement of judgments and pleading. Kharas, $A$ Century of Law-Equity Merger in New York, 1 SYRacuse L. REv. 186, 187 n.16, 188, 199 (1949). However, little justification exists for preserving such differences and the contemporary trend is to eliminate them in the search for "complete coalescing of law and equity actions." See Clark, Code Pleading and Practice Today, in FIELD CENTENARY ESSAYS 55, 64 (Reppy ed. 1949).

Waiver of jury trial, either affirmatively or by non-demand, very frequently avoids the question of right to a jury. The statistics are impressive. See Pike and Fischer, 
None." No basic attribute, common to all rational systems of judicial administration, compels these hyphenated tags. It is possible by constitutional provision ${ }^{8}$ or legislative order ${ }^{8}$, to require jury trials in all equity suits. It is likewise possible, in the absence of constitutionally imposed disability, ${ }^{10}$ for a legislature to cut across the law-equity line in requiring jury trials, e.g., in all suits brought for the recovery of money. ${ }^{11}$ The most common Constitutional provisions, however, are expressed in terms of the right remaining inviolate. ${ }^{12}$. Today, then, under a fused system of law and equity, we are still beholden to the old rules, wherever the test on the right to jury trial is an historical one. ${ }^{13}$ To that extent, at least, the solution of the procedural problems of tomorrow lies in the practice of yesterday. Yet the practicalities have changed. Foremost is the removal of the Damocletian sword of the statute of limitations. Denial of equitable relief, coupled with refusal to retain jurisdiction in equity for the award of damages, need no longer result in dismissal of the suit. ${ }^{14}$ Transfer to a jury docket is a penalty less severe and more in keeping with the philosophy of minimizing for litigants the adverse effects of the procedural errors

Pleadings and Jury Rights in the New Federal Procedure, 88 U. of PA. L. Rev. 645, 646-8 (1940), and for later figures CLARK, Code Pleading 93 n.47 (2d ed. 1947). The problem may be also avoided by both parties and the court consenting to jury trial of an equitable issue under the provisions of FED. R. CIV. P. 39(c). Likewise where one party demands jury trial of an equitable issue and neither the other party nor the court objects the jury's verdict has the effect of a common law verdict. Kelly v. Shamrock Oil \& Gas Corp., 171 F.2d 909 (5th Cir. 1949), cert. denied, 337 U.S. 917; 5 Moore, Federal Practice $\int 39.11$ (2d ed. 1951).

8. As in North Carolina and Texas. See Cook, Cases \& Materials on EQUITY, Note on Right of Trial by Jury in Equity Cases, 1178 (4th ed., Van Hecke, 1948) for citation to constitutional provisions, collected cases and commentary.

9. As in Georgia and Tennessee, ibid.

10. Statutory requirement of jury trial in equity has been held unconstitutional in some jurisdictions. Brown v. Kalamazoo Circuit Judge, 75 Mich. 274, 42 N.W. 827 (1889); Callanan v. Judd, 23 Wis. 343 (1868); McCurntock, EQuity 29 (2d ed. 1948) ; Clark, op. cit. supra note 7 , at 102. Cf. the argument of Vanderbilt, C. J. in Steiner v. Stein, 2 N.J. 367, 380, 66 A.2d 719, 725 (1949) construing a statute as not requiring jury trial on an issue formerly disposed of in equity because an opposite construction would have rendered it unconstitutional.

11. Examples are collected in CLARK, op. cit. sitpra note 7, at 95.

12. Id. at 91.

13. Even where statutes appear to be specific they are often read with an eye to former practice. City of Syracuse v. Hogan, 234 N.Y. 457, 138 N.E. 406 (1923). "What has happened is that the statutory terms have-quite sensibly-been in the main interpreted in the light of history. .. " CLARK, op. cit. supra note 7 , at 100 .

14. As Clark pointed out a quarter century ago, "Even in states where law and equity are not blended, the complaint in a case wrongly brought in equity is stot dismissed but is transferred to the lare side of the concrt." The Union of Lane and Equity, 25 CoL. L. REv. 1, 9 (1925). The italics are his, apparently a result of the "dismay" with which he yiewed some of the New York decisions. They should not, and in context do not, obfuscate the fact that where law and equity were administered in two entirely separate judical systems such transfer was impossible. Should amendment of the complaint be required after the statute had run a problem might arise. FED. R. CIv. P. 15(c) provides for relation back to the date of the original pleading in such circumstances and a similar result would be achieved "in all but a few jurisdictions" if not everywhere. CLARK, op. cit. supra note $7, \S 118$ and cf. the New York experience considered in Kharas, supra note 7 , at 196. 
of counsel. The basic purposes of the "statute of repose" require no more. ${ }^{15}$ Aberrations aside, counsel's poor judgment in choosing a chancellor rather than judge will not terminate the litigation. ${ }^{16}$

Other impressive economies are available today as a result of fusion. Plaintiff may present for adjudication two issues, the one legal, the other equitable. Free joinder and efficient administration can combine to produce but one trial with only the duty of decision divided between judge and jury. ${ }^{17}$ The evidence will be presented but once, with the possibility of further testimony before the judge alone, should it be needed. ${ }^{18}$ Not every case is appropriate for this technique. If the evidence on the legal issue is unrelated to that on the equity problem, no advantage may result from trying them together. ${ }^{18}$ Yet

15. The purposes of the statute are considered in Developments in the LawStatutes of Limitations, $63 \mathrm{HARV}$. L. REv. 1177, 1185 et seq. (1950). The situation considered in the text should be compared with successive trials because of error, hung juries, or verdicts against the weight of the evidence.

16. In New York, where dismissal has on occasion resulted from an improper law-equity 'choice (see note 14 sipra), a statute provides that plaintiff may bring a second action within a year after termination of the unsuccessful proceeding. N.Y. Crv. Prac. Act \$23. Possible difficulty in obtaining service and the fact that defendant may become unable to satisfy a judgment remain objections to dismissal. See Kharas, supra note 7, at 197. Added pressure toward settlement may also be noted. New action after failure of former action is considered generally in $63 \mathrm{H}$ ARV. L. REV. 1177,1243 (1950).

17. Elkins v. Nobel, 1 F.R.D. 357 (E.D. N.Y. 1940); Mealy v. Fidelity Nat. Bk., 2 F.R.D. 339 (E.D. N.Y. 1942) ; Munkacsy v. Warner Bros. Pictures, Inc., 2 F.R.D. 380 (E.D. N.Y. 1942) (timely demand for jury trial as to one count but not as to others). A jury impaneled because of proper demand may be utilized as an advisory jury on issues being tried to the court, Dellefield v. Blockdel Realty Co., 1 F.R.D. 689 (S.D. N.Y. 1941), rev'd on other grounds, 128 F.2d 85 (2d Cir. 1942), but the case may be of such complexity that an advisory verdict would involve added confusion in the form of submission to the jury and on that ground will be refused. Ford v. C. E. Wilson \& Co., Inc., 30 F. Supp. 163 (D. Conn. 1939). The opinion in the last-cited case illustrates the current primary concern with trial convenience as the following extract will demonstrate: "On the day of trial (November 20, 1939) the parties will proceed precisely as though trying to the jury both the first count and the second count viewed as charging actionable fraud, and the rulings on the evidence will be made as though no other issues were before the court. The court, however, will accept all evidence which is received in the jury trial for any proper bearing it may have upon the second count viewed as a cause of action in equity. After the jury has been charged and has retired to deliberate, the court will proceed to hear additional evidence on the equitable cause stated in the second count. There will be neither need nor permission to reiterate evidence already received in the jury trial; but any evidence theretofore offered and excluded in the jury trial may again be offered for its bearing on the second count viewed as a cause of action in equity.

"The presiding judge will of course have discretion to await a verdict of the jury before embarking upon a further hearing of evidence on the equitable issues. As we have seen, a verdict against the Bank might make it unnecessary to decide the equitable issues. However, the parties should be in readiness to proceed forthwith when the jury retires. For a defendant's verdict would apparently still leave open equitable issues, and the judge may feel that it is better to take any additional evidence thereon forthwith, while the parties and witnesses are in attendance, rather than to wait for the verdict of the jury." Id. at 166. See United States v. Yellow Cab Co., 340 U.S. 543, 555-556 (1951).

18. See authorities cited in note 17 supra. Some confusion is said to have been experienced as a result of a jury's being allowed to hear evidence addressed solely to non-jury issues. This can, of course, be avoided by excusing the jury.

19. See 5 Moore, Federai Practice $\Uparrow 39.12$ (2d ed. 1951) on Sequence of Trial. 
even where they are separated for trial some economy may result from merger. ${ }^{20}$ These current techniques, combined with skilful use of pretrial hearings ${ }^{21}$ may be of help on the problem of clean-up. Assume plaintiff has sued for specific performance of a contract, requesting damages in the alternative. If the court denies specific performance, and further refuses to award damages in equity, a further trial before a jury will be indicated. This will be true even though a great deal of the evidence presented in the first trial will have to be repeated. To prevent this situation, court and counsel may desire, at pre-trial, to canvass the desirability of impaneling a jury to sit from the beginning. ${ }^{22}$

It would be wrong to suggest that there need be no procedural cost to granting jury trial after refusal of equitable relief. Second trials are probably the rule rather than the exception. Potential docket delay results in more than inconvenience; it may be reflected in the amount of a settlement. Extra days in court may result in substantially larger attorneys' fees. If an appeal has been successful on remand without right to jury trial, additional testimony on a single issue before the same trial judge may be sufficient for final adjudication, while in the same situation a complete retrial would be necessitated if jury trial were required. ${ }^{23}$ In short, merger is not successful in eliminating altogether the added cost of trial by jury, although it can be credited with substantial economies.

It might be argued that our fused system requires re-evaluation of the clean-up rule in situations where a defendant was denied trial by jury on a legal issue primarily because the penalties which a twocourt system imposed on the plaintiff were too onerous--penalties now

20. Where the claims are totally unrelated but the witnesses necessary for the adjudication of each are the same, as may be the case where plaintiff has joined claims on two separate sales transactions, it may be possible in some courts to schedule the trials one after the other. Orenstein v. United States, 191 F.2d 184 (1st Cir. 1951) indicates that in successive trials of related issues the doctrine of collateral estoppel may be called into play. "The order of the trial is in the discretion of the district judge. Since the cause of action ... for injunction and restitution is equitable in nature, the court in disposing of that claim is entitled to make findings of fact on the issues of violation and the amount of the overcharges without participation by a jury. Determinations of fact so made, if not 'clearly erroneous,' are binding on the defendant, who is not entitled to relitigate such issues before a jury in the disposition of the cause of action for treble damages. . . " Id. at 190. Cf. Bruckman v. Hollzer, 152 F.2d 730 (7th Cir. 1946).

21. Venn-Severin Machine Co. v. John Kiss Sons Textile Mills, 2 F.R.D. 4 (D. N.J. 1941) is a short opinion following a pre-trial conference and written to guide counsel in preparing a. pre-trial order where a law-equity choice was involved.

22. See infra p. 345 for fuller discussion. Counsel for plaintiff will have to consider the tactical disadvantage of emphasizing the likelihood of denial of equitable relief while counsel for defendant may, in some circumstances, prefer a less speedy adjudication. Also see Baran v. Goldberg, infra note 101, and note 104 infra, Morris, Jury Trial Under the Federal Fusion of Law and Equity, 20 TEx. L. REv. 427, 428429 n.6 (1942).

23. Gulbenkian v. Gulbenkian, 147 F.2d 173, 177 (2d Cir. 1945). 
eliminated, or reduced. It usually makes sense to abandon a rule when the reason behind it has gone. Justification for the survival of historical rules, however, may be found in factors totally unrelated to the forces which gave rise to the rules some generations previous. In such cases we normally say that new and different reasons have replaced the old ones. Thus, strong anti-jury feeling may make it desirable that code practice does not extend, as it may not contract, the jury area. Abandoning understatement in the interest of accuracy, one is obliged to report that a prime objective of the united procedure has been to prevent extension of the province of the jury. As James described the second of three objectives, "The right of jury trial should not be expanded. This method of settling disputes is expensive and dilatory-perhaps anachronistic. Indeed the number of jury trials should be cut down. . . ."24 In the fifteen years since James wrote, the pendulum has, in some respects at least, begun to swing the other way. Various factors have played their part in accentuating the significance of the jury as a desirable political institution, for which sacrifice of "efficiency" is a price worth while. ${ }^{25}$ For our purposes, it will suffice to posit no general policy in favor of either extension or contraction of the right to jury trial. We may thus focus on the special factors presented by some of the clean-up situations. ${ }^{26}$

Equity jurisdiction to adjudicate legal issues in order to avoid multiplicity of suits is of wide scope. Limiting the area of inquiry to

24. James, Trial By Jury and the New Federal Rules of Procedure, 45 Y ALE L.J. 1022, 1026 (1936) ; Morris, Jury Trial Under the Federal Fusion of Law and Equity, 20 TEx. L. REv. 427 (1942); McCormick, The Fusion of Law and Equity in United States Courts, 6 N.C.L. REv. 283, 295 n.25 (1928). FED. R. CIv. P. 38(d) providing for waiver of jury trial unless demanded, and the many similar state provisions, has served to reduce jury trials. CLARK, op. cit. supra note 7 , at 116 . Adoption of such provisions for particular urban districts only, as in New York, is revealing.

25. Dissenting in Galloway v. United States, 319 U.S. 372, 396406 (1943), a civil case, Mr. Justice Black spoke strongly for an unemasculated Seventh Amendment. Though the case involved direction of a verdict, the rationale of the dissenters is of broad significance. "'[T] cratic government, and the judiciary's desire for the orderly supervision of public affairs by judges" is characterized as "the heart of the issue." Compare the early American opposition to courts of equity on political grounds which is, of course, a familiar story. For a very recent discussion of a phase of this opposition see Curran, The Struggle for Equity Jurisdiction in Massachisetts, 31 B.U.L. REv. 269, 271 (1951).

Some judges are reported to prefer a jury wherever credibility of the witnesses is involved in order to avoid the onus of decision. But cf. p. 331 infra.

26. The clean-up rule remains well recognized. Steiner v. Stein, 2 N.J. 367 373, 66 A.2d 719, 721 (1949) ("a cardinal principle of equity") ; Bereslavsky v. Kloeb, 162 F.2d 862, 863 (6th Cir. 1947) (affirming the Chancellor's 'historic power to dispose of the whole case as Chancellor."), cert. denied, 332 U.S. 816 (1947); Bellavance v. Plastic-Craft-Novelty Co., 30 F. Supp. 37 (D. Mass. 1939) (rejecting "plaintiff's contention that since the new rules abolish all distinction between Law and Equity, the doctrine - does not now obtain" and citing NLRB v. Jones \& Laughlin Steel Corp., 301 U.S. 1, 48 (1937), which found the Seventh Amendment inapplicable to cases awarding damages as an incident to equitable relief); Gulbenkian v. Gulbenkian, supra note 23. 
cases in which the equitable remedy is denied in the "discretion" of the chancellor leaves a wide variety of tort and contract claims. ${ }^{27}$ In particular it will prove helpful here to consider in some detail a few contract situations in which equitable relief has been denied, to observe how clean-up has been applied in them, and to examine the factors which are operative in the exercise of the chancellor's discretion to award damages, or to refuse them and leave the plaintiff to seek relief from a jury. Preliminarily, however, a more general survey of the chancellor's notions about juries and of early legislative control of clean-up is indicated.

\section{The Chancellor Seeks a Jury}

Many of the cases in which equity has retained jurisdiction to award damages by way of clean-up conclude by making provision for jury trial. ${ }^{28}$ This seeming anomaly requires consideration of the chancellor's flirtation with the system of the twelve tried and true. It was a vicarious affair at its best, often identified among the initiated by polysyllabic Latin: quantum damnificatus.

There was good reason for the chancellor's interest in trial by jury. His own procedure for resolution of issues of fact was woefully inadequate. Limited to written evidence in the form of depositions, the chancellor was handicapped, often to the point of ineffectiveness. Small wonder that he sought an ameliorative technique-the device of submitting an issue of fact to a law court for trial there. Paradoxical though it may seem, the jurors were no essential aspect of the award of an issue. They were not viewed as, in themselves, better triers of the fact or as a means for sampling community sentiment. They were, in a way, an unnecessary appendage to a system of trial which permitted oral testimony. ${ }^{29}$ In this context it makes sense

27. Cases of injunction against nuisance may result in conditional decrees which grant equitable relief unless defendant pay a specified sum as damages. See authorities collected in Keeton and Morris, Notes on "Balancing the Equities," 18 TEx. L. REv. 412, 420-421, n.23 (1940). Since, in theory at least, the final judgment does award an equitable remedy the doctrinal considerations are somewhat different.

28. v. White, 3 Swans, 108 n., 36 Eng. Rep. 792 n. (between 1706 and 1713); City of London v. Nash, 3 Atk. 512, 26 Eng. Rep. 1095 (1747); Phillips v. Thompson, 1 Johns. Ch. 131 (N.Y. 1814).

29. In Milkman v. Ordway, 106 Mass. 232, 255 (1870), the court finds objections to trial of the amount of damages in equity "still further removed in this Commonwealth" because of the then recent statute which provided that "in proceedings in equity the evidence shall be taken in the same manner as in suits at law." In Fisher v. Carroll, 46 N.C. 27,28 (1853), it was pointed out that a chancellor, "considering the inefficacy of written testimony, and the very defective manner in which depositions are usually taken, and the many advantages of an examination of the witnesses, in the presence of a jury" might award an issue.

In Berry v. Van Winkle, 2 N.J. Eq. 269, 275 (1839), the chancellor stated, "In all cases resting in damages only it is certainly more in accordance with our system of jurisprudence, that they should be ascertained at law, where a jury can pass upon 
for a judge to speak of directing an issue to a jury "for the purpose of collecting additional evidence to enable [the chancellor] to decide the cause." 30

The conception of the law court as an aid in the chancellor's trial of an issue of fact explains the control retained by equity over the proceedings. Equity named the issue, e.g., quantum damnificatus for an inquiry into the amount of damages. It was the chancellor who determined exactly what should be tried by the judge and fact-finders. The feigned issue "wherein the pretended plaintiff declares that he laid a wager of $\mathfrak{E 5}$ with the defendant that $A$ was the heir at law to $B$," 31 or some other fictitious allegations were dictated by the equity court. In 1814 a New York decree which called for jury trial ordered that "the plaintiff shall declare, in assumpsit, that the defendants promised to pay him as much as he reasonably deserved to have for his said damages and compensation, or to that effect; and to which declaration, the plea shall be non-assumpsit; on the trial, the plaintiff shall not set up any agreement between him and the defendants, . . . and the defendants shall admit their assumption to pay the plaintiff so much as he reasonably deserved . . . and the jury are to allow, in their assess-

them and the witnesses are seen and examined in open Court." (It should be noted, however, that reference to a master did not satisfy the court as being equivalent to jury trial.) Atrinson \& Chadbourn, Cases and Materials on Crim. Procedure 592 (1948), in explaining equity's reluctance to adjudicate title to land state, "It was felt that there should be a right to trial by jury of such questions. An even greater factor may have been that the secret examination of the witnesses in the equity suit was ill adapted to the trial of title." See also McClintock, EQuity 29 (2d ed. 1948).

One might have thought it simpler to bring the jury to equity, or to allow for oral evidence before the chancellor. Blackstone states the impossibility of the former, 3 BL. Comm. *452; does not mention the latter. At a later date when a jury in equity was possible the usual practice remained, in some places at least, to send the issue to law because of "the inconvenience and expense of having a jury, and the witnesses," come to equity. Fisher v. Carroll, supra, at 29.

Compare the following passage from Fonblanque on Equity (urging a broader concurrent jurisdiction for equity) quoted in 1 STORY, EQUITY JURISPRUDENCE $82 \mathrm{n} .2$ (1836) and characterized by the latter as worthy of wide dissemination: "as the mode of proceeding in Courts of Law requires the plaintiff to establish his case, without enabling him to draw the necessary evidence from the examination of the defendant, justice could never be attained at law in those cases, where the principal facts, to be proved by one party, are confined to the knowledge of the other party. In such cases, therefore, it becomes necessary for the party, wanting such evidence, to resort to the extraordinary , powers of a Court of Equity, which will compel the necessary discovery ..."

Blackstone also reports a practice of equity when a "question of mere law arises" to "refer it to the opinion of the judges of the court of king's bench or common pleas, upon a case stated for that purpose, wherein all the material facts are admitted, and the point of law is submitted to their decision; who thereupon hear it solemnly argued by counsel on both sides, and certify their opinion to the chancellor." $3 \mathrm{BL}$. Comms. *452-3.

30. Clifford, J. in Goodyear v. The Providence Rubber Co., 10 Fed. Cas. No. 5,583 at 717 (C.C.R.I. 1864).

31. 3 BI. CoMm. *452. 
ment of damages, interest upon the amount of damages they may find ... to the time of rendering the verdict. . . ." 32

The chancellor's control was not at an end. The verdict rendered, it was returned to the equity court. $^{33}$ Costs, even of the trial at law, did not necessarily follow the verdict; they were in the chancellor's discretion. $^{34}$ Finally, and most significantly, the award of a new trial was in the hands of the chancellor; ${ }^{35}$ soon he was at liberty to disregard the verdict, rendering judgment as his own informed, but unheeding, conscience dictated. ${ }^{36}$

A word must here be said of trial by jury as of right in an equity suit. ${ }^{37}$ Pre-reform, many years before merger or fusion, such a right was recognized in England-not in all cases, of course. ${ }^{38}$ Prima facie its existence, however narrow in scope, seems in conflict with the analysis suggested above, for the right of a litigant to trial by jury can hardly be compatible with the chancellor's privilege of treating a verdict as no more than advisory. Consider, however, the following exposition of British equity practice: "In a suit for establishing a will the heir at law is, by the long-established practice of the court, entitled to an issue devisavit vel non. But he cannot be compelled to decide whether he will or not require such issue until the hearing of the cause,

32. Phillips v. Thompson, 1 Johns. Ch. 131, 152 (N.Y. 1814).

33. Standen v. Edwards, 1 Ves. Jr. 133, 30 Eng. Rep. 266 (1790) ; 2 Harrison, Chancery Practice 508-511 (Newland ed. 1808); 2 id. 124-126 (1st Am. ed. 1807) (the entire chapter on issue was not included in the first English edition).

"The distinction between the suspension of proceedings in an equity suit, with leave to a party to bring a suit at law, or directing an action and an issue out of chancery, is well settled. If the cause is allowed to stand over with leave to bring an action, or directing an action at law, the action is prosecuted in compliance with the practice and proceedings in ordinary actions at law. Bills of exceptions may be taken at the trial, and the proceedings are reviewable by rule to show cause and writ of error in the usual manner, and judgment at law will be entered, which will be accepted in the equity court as a finality. . . . But where an issue is sent out of chancery, the whole proceeding is under the control of the chancellor. No bill of exceptions can be taken, and no judgment entered; the circuit record and postea are sent to the court of chancery, and the conduct and result of the trial are subject to review in that court only." American Dock \& Improvement Co. v. Trustees for Public Schools, 37 N.J. Eq. 266, 269 (1883).

34. Standen v. Edward, supra note 33.

35. Ibid.; Faulconberg v. Peirce, Amb. 210, 27 Eng. Rep. 140 (1754) ; HARRIson, op. cit. supra note 33.

36. See Le Guen y. Gouverneur \& Kemble, 1 Johns. 436, 507 (N.Y. 1800) ; Fisher v. Carroll, 46 N.C. 27,30 (1853).

37. The jury, of course, did not sit in equity, but for our purposes the effect was substantially the same.

38. "Trial by issue, indeed, forms no necessary appendage to a court of equity even in the parrent country, and never did, except that, perhaps, an heir at law, where the object of the suit was to divest him of a freehold estate of which his ancestor died seised; or the rector of a parish, where his common-law right to tithes was drawn in question, might be entitled to issues as matter of right." Clfford, J. in Goodyear v. Providence Rubber Co., 10 Fed. Cas. No. 5,583 at 717 (C.C.R.I. 1864). Story states award of an issue to be discretionary with the chancellor "except in questions of the validity of wills." 2 STORY, EQUITY JURISPRUDENCE $798 \mathrm{n} .1$ (13th ed. 1886). 
when he will have had an opportunity of considering the evidence taken in the cause, and of satisfying his mind, so far as that evidence extends, whether he should or not have the matter investigated by the viva voce examination of the witnesses on the trial of an issue." 38

It should be noted that the heir's right to jury trial is, consistent with what has been suggested earlier, explained in terms of the need for oral testimony. Is it possible to separate the right to a type of evidence (oral proof) from the right to who shall weigh the evidence (a jury verdict)? History finally answered in the affirmative, but an additional factor played an important role. That factor, revealed in the quoted extract, should be considered first. It concerns the inefficient procedure by which the heir might have, as of right, two trials of the same issue, the first in traditional equity fashion, the second at law. In cases of discretionary award of an issue to a jury by the chancellor, an analogous requirement developed which provided that all proofs in equity must already have been taken and published before an issue could be awarded. ${ }^{40}$ This was a costly business, which gave rise to an understandable reluctance to award issues. ${ }^{41}$ A defense of this procedural ineptitude, a rule designed to stimulate res non-adjudicata, might run as follows: Award of an issue is designed to complement equitable procedure by resort to law where equitable procedure is deficient. One cannot determine whether equity's procedure will suffice to resolve the factual controversies in any particular case until it has been tried. Hence, if deficiency there be, it must be demonstrated by trial. Only with such a premise implicit in his argument could Kent establish as a necessary condition for award of an issue that "the testimony be so contradictory" that "it becomes requisite to judge merely on the credibility of witnesses." 42 Here, then, is a requirement of an inadequate remedy in equity. It is a rule given life by logic, if logic this be, rather than experience.

It was not to be expected that such a procedural system would remain invulnerable to attack. The substantial cost of an award of an issue was such as to exert pressure on chancellor and litigants alike to

39. $2 I d$. at $781 \mathrm{n} .2$ (13th ed. 1886) quoting from the "report of the Chancery Commissioners to Parliament in March, 1826, and the explanatory paper of Mr. Beames (p. 84)." The procedure may appear strange in this country. 2 Id. at $780 \mathrm{n}$. (c). The text at 780 describes the suit as one "in equity brought by devisees and others in interest to establish the validity of a will of real estate; and thereupon to obtain a perpetual injunction against the heir at law and others to restrain them from contesting its validity in future." (1864).

40. See Goodyear v. Providence Rubber Co., 10 Fed. Cas. No. 5,583, at 717

41. Le Guen v. Gouverneur \& Kemble, 1 Johns. 436 (N.Y. 1800) ; 2 SToRx, op. cit. sipra note 39 , at 808 .

42. Le Guen v. Gouverneur \& Kemble, supra note 41 , at 507 . To the same effect see Ebling Brewing Co. v. Heirloom, Inc., 1 N.J. 71, 78, 61 A.2d 885, 888 (1948). 
accept the result. There was a marked reluctance to grant new trials. ${ }^{43}$ Yet a chancellor's dissatisfaction with the jury's verdict, in the early cases, occasioned a retrial rather than an overriding finding. The chancellor's insulation from the trial at law may account for this in part, although he did receive an evaluation of the verdict from the common law judge.44 The notion that the jury trial was of right may have had an effect, and who can say that the desire to have the reaction of a dozen laymen was not a factor. ${ }^{45}$ At law there were even more stringent limitations on disregarding the jury. ${ }^{46}$ How far should the chancellor go?

The chancellor went far. New factors came to the fore. Chancellors hear and observe the witnesses in their courts, resort to the master is frequent, and advisory juries are available. Repeated trials as a result of disagreement between the chancellor's conscience and his conscience-informers are no longer the problem they were. Reluctance to override the verdict in appropriate cases seems more readily overcome than in yesteryear. ${ }^{47}$ Further, a duty is imposed on the chancellor, where he entertains no doubt as to the proper finding of fact, to decide on the basis of his own resolution of the factual controversy regardless of the verdict. ${ }^{48}$

43. Lord Cottenham wondered whether "such an issue should be directed without putting the parties to an undertaking to abide by the result." Ansdell v. Ansdell, 4 My. \& Cr. 449, 454, 41 Eng. Rep. 174, 176 (1840).

See also 2 STORY, op. cit. supra note 39 , at 808-809.

44. In Standen v. Edwards, 1 Ves. Jr. 133, 30 Eng. Rep. 266 (1790), the common law judge "certified in favour of the verdict" but a new trial was nevertheless granted by the chancellor. In Bates v. Graves, 2 Ves. Jr. 288, 30 Eng. Rep. 637 (1793), the judge who tried the case died and the chancellor refers to the disadvantage of not "knowing judicially" the former's opinion of the evidence. The chancellor did consult the judge's notes upon the trial which were made available to him.

45. "It was not an unusual practice in the Court of Chancery, for that court to send a case for trial by a jury in matters involving the assessment of damages where it appeared to be more appropriate for a jury to pass upon such questions, even in cases where the facts were such as were sufficient to give a court of equity jurisdiction, and on the finding of a jury on such facts, to render the proper judgment. These remarks may be applied with much more force where the cause of action rests more in tort than in contract." Genet v. Howland, 45 Barb. 560,572 (1866). See also the AtKInson \& CHADBourn quotation, supra note 29. Variations of the Geret case statement, indicative of some concern for layman reaction, are not uncommon. See, e.g., Woodman v. Freeman, $25 \mathrm{Me}$. 531, 547 (1847) ; Iszard v. Mays Landing Water-Power Co., 31 N.J. Eq. 511, 524 (1879), aff'd per curiam, 34 N.J. Eq. 556 (1881), with its implication of another class of right to an issue of quantum damnificatus.

46. Faulconberg v. Peirce, Amb. 210, 27 Eng. Rep. 140 (1754); Standen v. Edwards, supra note 44, at 136 n.1, 30 Eng. Rep. 267 n.1.

47. The verdict must be treated "as an individual does the opinion of a friend, whom he is at liberty to consult." Fisher v. Carroll, supra note 36, at 30 .

48. The Ebling case, supra note 42, quotes with approval an earlier opinion which stated that an advisory jury's only object is to relieve the chancellor of doubt, and continued, "As no such doubt exists it is my duty to decide the case upon the evidence before me." Id. at 78,61 A.2d at 888. In Carroll v. Bullock, 207 N.Y. 567, 101 N.E. 438 (1913), it was held that despite an advisory verdict, review on appeal would be considered "precisely as though the case had been tried without the intervention of a jury." Similarly under the Federal Rules the judge is under a duty to make his 
In sum, then, today's chancellor may still search for a jury. A sampling of laymen's opinion by way of advice is available to him, if he wants it. A distinguished jurist, however, has said that in some places assignment to a courtroom without jury box is sufficient deterrent to the seeking of such advice. Furthermore, as we have seen, a duty to reject advisory verdicts may be greater in equity than at law.

To the litigant a jury in equity is in no real sense trial by jury. If it is the latter he desires, the road to his quest, under a fused system, is by way of a trial "at law" of the given factual controversy. The jurist need not change his gown from that of the chancellor to that of the judge; he may even wear both vestments simultaneously. For the litigant's right assuredly to be effective, the jurist, as regards that particular issue, must sit in a role other than mere chancellor. ${ }^{49}$ In short, despite the history of jury trial by award of an issue, today we may approach the problem of clean-up with the premise that a narrower scope of equitable jurisdiction will in a real sense allow for trial by jury, and a wider sweep will not. ${ }^{50}$

\section{The Chancellor Has a Statute}

The important consequences of clean-up to the litigants, particularly to plaintiffs who stood to lose the right to any remedy, make legislative intervention understandable. Much discussed in American opinions and texts ${ }^{51}$ is a British statute addressed to the problem of when equity courts might take upon themselves adjudication of legal issues, thereby denying jury trial. It appears to state a clean-up rule of the widest latitude, controlled only by the discretion of the chancellor. Commonly referred to as Lord Cairns' Act it provides: "In all cases in which the court of chancery has jurisdiction to entertain an

own findings of fact even when an advisory verdict has been rendered. FED. R. Crv. P. 52(a). 5 Moore, Feneral Practice 726 (2d ed. 1951).

A New York statute passed in 1838 providing that jury verdicts on feigned issues should be conclusive unless a new trial was ordered by the court in which the issue was tried was repealed a year later. See Carroll v. Bullock, sipra, at 577, 101 N.E. at 440. See 15 MIN . I. REv. 478 (1931) for a sharp criticism of a line of Minnesota authorities limiting the chancellor's right to disregard advisory verdicts.

49. Under complete fusion, the court is, of course, not properly referred to as either judge or chancellor. Convenience of ready distinction in the context of this type of discussion is not intended as dissent from Clark's protest against anachronistic terminology. See Clark, Code Pleading 111 (2d ed. 1947).

50. This is particularly true where jurists would be inclined to exercise their discretion against jury trial. But of. the judicial attitude reported in note 25 supro.

51. New York City v. Pine, 185 U.S. 93, 107 (1902) ; Milkman v. Ordway, 106 Mass. 232 (1870); Wright v. Scotton, 13 Del. Ch. 402, 121 Atl. 69 (1923); Cox v. New York, 265 N.Y. 411, 193 N.E. 251 (1934); 2 Sutherdand, DaMages $\$ 590$ (4th ed. 1916); 1 Poneroy, EQUITY 441 (5th ed. 1941); Lewis, Damages Given in Equity in Lieu of a Specific Performance, 50 AM. L. REg. 394 (1902); 31 VA. L. REv. 705 (1945); 38 HARv. L. REv. 667 (1925). 
application for an injunction against a breach of any covenant, contract or agreement, or against the commission or continuance of any wrongful act, or for the specific performance of any covenant, contract or agreement, it shall be lawful for the same court, if it shall think fit, to award damages to the party injured, either in addition to or in substitution for such injunction or specific performance; and such damages may be assessed in such manner as the court shall direct." 52

Confusion confounds appraisal of this statute, its origin, its "repeal" and its contemporary effect. It has been said that "under this statute the court would not interfere to award damages where it would not have interfered to grant relief before," 53 that it has been repealed ${ }^{54}$ and yet remains today "an important feature of modern English equity." 55

One source of the difficulty with respect to the statute may be found in the reading of some of the early cases. Here, as in other areas of the law, the attempt to generalize too broadly, is an unhappy one. In evaluating the precedents it is not too profitable to inquire generally whether or not an equity court will clean-up after denying specific performance. A more fruitful inquiry is directed at first ascertaining the reason for denial of specific relief. Contrast a case in which near-fraud results in a price so unfair that it shocks the chancellor's conscience with a case in which the defendant sells a unique chattel to a third party pendente lite. In both, no doubt, specific relief must be denied. Certainly, however, the effects of awarding damages in substitution for specific performance would vary in the two cases, and, as a result, the desirability of clean-up in the respective situations might be substantially different. ${ }^{56}$ In the former the standard measure of damages would give the "wrongdoer" the benefit of his impropriety. In the second, a money judgment would relieve an unsuspecting, reasonable plaintiff from the costs and delay involved in starting another action anew. Without identifying the law that ought to be with the law that is, one would nevertheless be put on notice that a narrower reading of the cases may be required. The validity of this basic approach is common to both British and American judicial systems despite differences between the problem of clean-up in England and its counterpart in this country. ${ }^{57}$

52. 21 \& 22 Vict., c. $27, \S 2$ (1858).

53. 2 SUTHERLAND, op. cit. supra note $51, \S 590$ citing Scott v. Rayment, considered infra p. 336.

54. 1 POMEROY, op. cit. supra note 51, at 441-442.

55. 31 VA. L. REv. 705, 706 (1945).

56. See discussion infra p. 340 et seq.

57. The absence of a constitutional requirement of trial by jury has been emphasized. 38 HARV. L. REv. 667, 671 (1925). Today in England the right to trial 
There is no doubt that British chancellors had, long prior to Lord Cairns' Act, assumed jurisdiction to award damages in lieu of ${ }^{58}$ specific performance. Some cases involved discretionary denial of specific relief and, in addition, circumstances which made award of damages in the same suit an equitable solution. ${ }^{59}$ In other cases there was no question about denying specific relief; it was impossible. Denton $v$. Stewart was such a case. ${ }^{60}$ Whether or not the sale by defendant to a third party occurred before or after plaintiff brought suit, it seems clear ${ }^{61}$ that plaintiff had no knowledge of impossibility when he brought his bill. Indeed he asked no damages. ${ }^{62}$ Greenaway v. Adams was another case where specific performance became impossible. ${ }^{.3}$ The Master of the Rolls, Sir William Grant, specifically found that defendant rendered herself incapable of performing the contract after the bill was filed. ${ }^{64} \mathrm{He}$, too, ordered reference to a master for determination of damages rather than dismiss the suit. Sir William, with a charming display of intellectual integrity, frankly admitted that he did not understand Denton $v$. Stewart, but yielding doubts to authority, followed it.

A few years thereafter came the undisputed progenitor of Lord Cairns' Act, Todd v. Gee. ${ }^{65}$ This was the case which made it so clear

by jury is restricted to a very few subjects (defamation and breach of promise to marry are the most prominent), SLESSER, ADMINISTRATION of THE LAW 55 (1948), and the discretionary power of the master to order a jury "is used sparingly." Odgers, Pleading and Practice 253 (12th ed. 1939).

58. In Wright v. Scotton, supra note 51 , the court does not discriminate between cases where specific performance was granted with "compensation" and those where equitable relief was denied and damages awarded "in lieu" of same. The distinction was of significance to many judges; see Lord Eldon in Todd v. Gee, 17 Ves. Jr. 273, 278, 34 Eng. Rep. 106, 107 (1810). Further, where a case included award of some equitable relief it did not present as difficult a clean-up problem.

59. - v. White, 3 Swans. 108 n., 36 Eng. Rep. 792 n. (between 1706-1713), specific performance of a lease of a way-leave over plaintiff's land, which way-leave had become useless to defendant. Consider also London v. Nash, 3 Atk. 512, 26 Eng. Rep. 1095 (1747) where the opinion talks clean-up but the court searched for another basis for equity jurisdiction. But cf. CHESHIRE \& FIFOOT, LAW of CoNTRACT 460 (2d ed. 1949): "A plaintiff who failed in a suit in equity for specific performance was originally driven to sue for damages at common law, and it was not until 1858 that the power to award damages as an alternative form of relief was conferred [by Lord Cairns' Act] upon the Court of Chancery." This statement, it should be noted, would cover impossibility situations as well. See note 60 infra.

60. 17 Ves. Jr. 276, 280 n. (1), 34 Eng. Rep. 107, 108 n.(1) (1786). Lewis, in his excellent article Damages Given in Equity in Lien of a Specific Performance, 50 AM. L. REg. 394, 395 (1902), also discusses an earlier case, Hedges v. Everard, 1 Eq. Ins. Abr. 18 pl. 7 (1699).

61. Lewis, supra note 60 , at 395 , emphasizes the point.

62. Sir Samuel Romilly so states specifically in 17 Ves. Jr. 276, 280 n. (1), 34 Eng. Rep. 107, 108 n.(1) (1786).

63. 12 Ves. Jr. 395, 33 Eng. Rep. 149 (1806).

64. Id. at 400-401, 33 Eng. Rep. at 151. Lewis' statement, supra note 60 , at 396 , that "There would appear to be no question but that plaintiff, at the time he brought his bill, knew of this [defendant's] assignment" seems in conflict, and appears to be unsupported.

65. 17 Ves. Jr. 273, 34 Eng. Rep. 106 (1810). 
that damages in lieu of specific performance could not be had in equity that statutory authority became necessary-or so the allegations run. ${ }^{66}$ Lord Eldon had before him a demurrer to a bill which prayed specific performance, or if good title could not be made, money damages. The demurrer was overruled on grounds which need not concern us here. In the course of the opinion, however, the Lord Chancellor indicated that if defendant could not make good title, plaintiff should have no damages in equity-his proper forum was law. Eldon's language is, if anything, circumspect and limited: "except in very special cases it is not the course of proceeding in Equity to file a Bill for specific performance of an agreement; praying in the alternative, if it cannot be performed, an issue or an inquiry before the Master, with a view to damages. The plaintiff must take that remedy, if he chooses it, at Law: generally, I do not say universally, he cannot have it in Equity." ${ }^{87}$

Some have purported to see a genuine need for remedial legislation as a result of Todd $v$. Gee, ${ }^{68}$ while others more acute in their analysis, have viewed the ensuing Act as unnecessary except as it dispelled doubts which had been raised by Eldon's statement. ${ }^{69}$ To say that Todd $v$. Gee had raised doubts concerning clean-up is no exaggeration. Indeed if Lord Cottenham be believed, no doubts remained; equity simply would not clean-up where specific performance had been denied. ${ }^{70}$

Dean Lewis has pointed out that Lord Eldon did not "overrule Denton v. Stewart, and did not even express the opinion that he would not follow Lord Kenyon in a similar case." 71 Why then did Todd $v$. Gee have this type of impact on the profession? Perhaps the answer is to be found in the fact that the precise distinctions in factual situations (more readily made so long after the fact) were not at that time considered of significance. In Greenaway $v$. Adams, discussed earlier, the Master of the Rolls had stated that clean-up was to be available where "the inability of the party to perform the contract grew out of

66. See, e.g., 31 VA. L. REv. 705, 706 (1945).

67. 17 Ves. Jr. 273, 279, 34 Eng. Rep. 106, 108 (1810).

68. See note 66 supra.

69. Wells, J. in Milkman v. Ordway, 106 Mass. 232, 257 (1870) ; State v. Sunapee Dam Co., 72 N.H. 114, 124, 55 Att. 899, 905 (1903).

70. In Sainsbury v. Jones, 5 My. \& Cr. 1, 3-4, 41 Eng. Rep. 272, 273 (1839) : "I certainly recollect the time at which there was a floating idea in the profession that this Court might award compensation for the injury sustained by the non-performance of a contract, in the event of the primary relief for a specific performance failing. . . . Lord Eldon, in 1810, in Todd $v$. Gee (17 Ves. 273) expressly overruled Denton $v$. Stewart, and, from that time, there has not, I believe, been any doubt upon the subject."

71. Lewis, supra note 60 , at 397 . 
an act done by the party, after the contract had been entered into." 72 The rule thus stated applies (1) to a plaintiff who comes into equity for specific relief only to find that his right is thwarted by a subsequent impropriety of defendant. It applies equally (2) to one who comes into equity for specific relief in good faith believing such relief possible, only to learn subsequently that a prior impropriety of defendant has made plaintiff's demand an impossible one. Finally, it applies (3) to the plaintiff who knows when he comes to equity that the relief he asks is impossible, but comes nonetheless because he would prefer the chancellor, rather than a jury, to determine damages. There is sound basis for clean-up in the first case. Refusal to award damages would give a defendant in default the power by his own act after suit is begun, to deny equity effective jurisdiction. In more practical terms, defendant would have avoided specific relief by making it impossible and in addition would have penalized plaintiff, in time and in money, for having sought the performance which, in the normal course, he would have received. Retention of jurisdiction in equity to award damages, rather than forcing plaintiff to pursue his remedy at law, would remove the threat of the statute of limitations, halt the mounting cost of litigation, and give the non-defaulting party a speedy adjudication of his rights. Far different is the third case put, where plaintiff knew when he brought suit that specific performance was impossible. To grant damages in lieu of specific performance here would allow a litigant to defeat his adversary's right to trial by jury by the simple expedient of asking for a type of relief which he knows he can not get, and, conceivably, may not even want. Case 2 eliminates bad faith, ' replacing it with error. Obviously, it poses a more difficult problem of balancing the competing interests. A diversity of result was to be expected and is, in fact, reflected in contemporary law. ${ }^{73}$ To suggest a single clean-up formula for these three diverse situations is neither realistic nor helpful. Confusion is invited, and as an invitee imposes a correlative standard of care on the reasonably prudent judge.

Even more revealing of lump-thinking on clean-up is an earlier dictum in the Greenaway case. It will be recalled that Sir William

72. 12 Ves. Jr. 395, 401-402, 33 Eng. Rep. 149, 152 (1806). It should be noted that Lord Eldon was more discerning. See 17 Ves. Jr. 273, 279, 34 Eng. Rep. 106, $108(1810)$.

73. Milkman v. Ordway, 106 Mass. 232 (1870). Authorities are collected and analyzed in 1 POMERox, EQUITY \$237f (5th ed., Symons, 1941); 5 MOORE, FEDERAI Practice 181 (2d ed. 1951); Pomeroy, Spectfic Performance \$ 477 (3d ed. 1926). Schottenfeld, Decrees for Damages in New Jersey, 5 U. of NEWARK L. REv. 371 (1940), discusses the problem among others in a survey of clean-up in that state. Some limitation on equitable jurisdiction to award damages to the plaintiff who knows when he brings suit that equitable relief is impossible may be needed to preserve the law-equity division. Cf. 16 CoL. L. REv. 326, 328 (1916) and the formulation suggested on p. 351 infra. See also 30 HARv. L. REv. 188 (1916). 
followed authority which he said he did not understand. He did, however, express his own, unfettered, views as follows: "The party, injured by the non-performance of a contract, has the choice of resort either to a Court of Law for damages, or to a Court of Equity for a specific performance. If the Court does not think fit to decree a specific performance; or finds, that the contract cannot be specifically performed, either way I should have thought there was equally an end of its jurisdiction; for in the one case the Court does not see reason to exercise the jurisdiction: in the other the Court finds no room for the exercise of it. It seems, that the consequence ought to be, that the party must seek his remedy at Law." 74 Cottenham did the same type of generalizing, which is undoubtedly what led him to conclude that Eldon had overruled Denton v. Stewart. ${ }^{75}$

So Lord Cairns' Act was passed. A decade later the Vice-Chancellor was to refuse clean-up saying: "If this Court would not have interfered antecedently to Lord Cairns' Act, it will not interfere now. ..." 76 Prima facie this would certainly seem to qualify as a reading of the statute "as though it were not there." On its facts, however, the Vice-Chancellor's decision is not shocking, and conceivably not even bad law. Plaintiff sued for specific performance of a partnership agreement. A long line of authority demonstrated that equity would not specifically enforce such contracts, and the court rejected plaintiff's argument that, nevertheless, under Lord Cairns' Act the case should be retained for damages. A tenable view of that statute might well be that it was intended to relieve the burden of the litigant who, in good faith, but with bad judgment-let us say, with reasonably bad judgment-sought equitable relief when all he had was a right to damages at law. Under such a view of the statute the holding, if not the language, of the Vice-Chancellor may be defended. ${ }^{77}$ And perhaps the

74. 12 Ves. Jr. 395, 401, 33 Eng. Rep. 149, 151-152 (1806). One year after Sir William decided Greenaway v. Adams he had before him Gwillim v. Stone, 14 Ves. Jr. 128, 33 Eng. Rep. 469 (1807) in which the issue was award of damages in addition to equitable relief. The latter involved "delivering up" an agreement of sale on the ground of defendant's defective title. Equitable relief was granted, but damages were denied without prejudice to an action at law. Greenazway v. Adams was distinguished on its facts, although doubts were expressed concerning the principle on which it rested. Contrast these two views of the case: "The case does not indicate that he was inclined to believe that his action in Greenaway $v$. Adams was incorrect." Lewis, supra note 60, at 396-397, n.9. “. . . Sir W. Grant, in 1807, in Gwillim v. Stone (14 Ves. 128) refused to follow his own decision in Greenaway v. Adams. - ." Lord Cottenham in Sainsbury v. Jones, 5 My. \& Cr. 1, 3, 41 Eng. Rep. 272,273 (1839).

75. See note 70 supra.

76. Scott v. Rayment, L.R. 7 Eq. 111 (1868). But cf. Bovill v. Hitchcock, L.R. 3 Ch. App. 417 (1868) (opinion by Lord Cairns).

77. Since Lord Cairns' Act is only permissive in terms, the decision in the Scott case, supra note 76, might have been placed on the basis of the Vice-Chancellor's discretion. This was not done, however. It should be noted that the case was decided on demurrer. 
genius of the common law lies in deciding cases rather than in articulating rules. ${ }^{78}$

There is no question but what Lord Cairns' Act did have a significant impact on British procedure, and, in certain areas, its provisions are not without importance today. ${ }^{79}$ However, under the Judicature Acts which enable "any judge of a Division of the High Court to grant any remedy, legal or equitable," Lord Cairns' Act is no longer basic in determining whether there shall be clean-up in equity where specific performance is denied. ${ }^{80}$ A legacy of curious legal reasoning, stamped with respectability in England and echoed in this country, ${ }^{81}$ is nevertheless deserving of mention. It is best illustrated by Hanbury who, in his current edition, inquires whether Lord Cairns' Act would permit damages in a case where "equity takes the neutral line," neither granting specific relief nor precluding the parties from turning to law. He instances the situation of Webster $v$. Cecil ${ }^{82}$ where, because of unilateral mistake, the contract price was set at $£ 1250$ instead of $£ 2250$. Denial of legal damages in equity is perfectly understandable as soon as one realizes that to grant them would inflict upon defendant the precise hardship the chancellor, in his discretion, is attempting to avoid. ${ }^{83}$ According to Hanbury, however, "the short answer" is to be found in "seven vital words in Lord Cairns" Act. Damages can indeed be awarded, but only in addition to or in substitution for specific performance. So in a case in which specific performance would have been inadmissible, damages cannot be awarded." 84 Unfortunately, however, the only time the problem of legal damages in substitution for specific performance arises is when, for one reason or another, specific performance is denied. The chancellor finds such relief "inad-

78. It was the good judge from Kansas who had no trouble deciding the case before him, but who found stating "the rule" so difficult that he finally abandoned the attempt with the observation: "If scientific or other considerations demand a formula governing the subject, whoever needs can phrase one. . .." Burch, J. in Zelliken v. Iynch, 80 Kans. 746 (1909). The problem concerned the mutuality rule. $C f$, Campbell, J. in Brown v. Kalamazoo Circuit Judge, 75 Mich. 274, 42 N.W. 827 (1889): "Theory amounts to nothing in the history of jurisprudence."

79. Leeds Industrial Co-operative Society v. Slack [1924] A.C. 851, noted 34 YALE L.J. 555 (1925), held that under the Act, or more accurately, under subsequent statutes which in effect keep Lord Cairns' Act alive, an equity court might grant damages in lieu of injunctions, even though no such would have been awarded at law. See also HANBURY, Modern EQUity 75, 627, 630 (5th ed. 1949).

80. HANBURY, op. cit. supra note 79, at 627 , with a discussion of the differences in scope between the two statutes at 631 .

81. 1 POMEROY, EQUITY $\$ 237 \mathrm{~b}$ (5th ed. 1941) and see discussion of the judicial echo infra at p. 343 .

82. 30 Beav. 62, 54 Eng. Rep. 812 (1861).

83. The question of damages was not discussed in the opinion although HANBURY, op. cit. supra note 79 , at 631 , points out that they may be awarded without having been asked.

84. Id. at 627. The emphasis is his. 
missible" because of impossibility, because of hardship, because of quasi-fraud, or for other reasons. ${ }^{85}$ If "inadmissible," a term not found in the statute, is used by Hanbury as a word of art, his "short answer" has no meaning unless the term be defined. Hanbury, however, was drawing on Chitty, whom he cites. In Lavery v. Pursell, ${ }^{86}$ a case in which specific performance had become impossible due to lapse of time, damages were also denied, on the following reasoning: 'It was suggested that after Lord Cairns' Act the Court of Equity could give damages in lieu of specific performance. Yes, but it must be in a case where specific performance could have been given. It was a substitute for specific performance. It did not give the old Court of Chancery a general jurisdiction to give damages whenever it thought fit, it was only in that kind of case where specific performance would have been the right decree and there were reasons why it would be better to substitute damages, but that could not apply to a case where you could not have given specific performance. As is well known, the Court of Chancery would not grant specific performance of an agreement for a holding for a year, the reason being that it was one of those matters which were best dealt with by damages, and another being the practical reason that you could not get your suit heard and obtain a decree within a year in ordinary course." Then finding that the right to be enforced ran only to a date already passed, Chitty concludes: "It would have been impossible to grant specific performance in this case, and that being so, it appears to me that the Plaintiff cannot recover any damages." 87

Chitty's. presentation is not satisfying. ${ }^{88}$ Impossibility of specific performance is held to make Lord Cairns' Act inapplicable. Yet a reading of the pre-statutory cases leaves the reasonable inference that at least some of the impossibility situations were intended precisely to be covered. Affirmatively, according to Chitty, Lord Cairns' Act may be applied where "specific performance would have been the right decree," but the case was best dealt with by the award of damages. Is it possible, in a case best dealt with by damages, for specific performance to be the "right decree"? 89

85. There are some cases of hardship or quasi-fraud where the chancellor :might either have awarded, or refused to award, specific performance without reversal for abuse of discretion. Here, if anywhere, specific performance would seem "admissible"-a non-reversible alternative. Yet these may be among the clearest cases for refusal of damages in equity, for exactly as in Webster v. Cecil supra note 82, damages would inflict upon the defendant the precise hardship the chancellor determined to avoid.

86. 39 Ch. D. 508 (1888).

87. Id. at 519. Emphasis added.

88. No attempt is being made here to evaluate the holding of the case nor to present all of the facts necessary for such evaluation.

89. See note 85 supra. 
It seems reasonable to say that in the post-statutory cases as in the pre-statutory cases there is an attempt to write the rules with too broad a sweep. Perhaps great minds prefer the universal to the particular. The problem before Chitty was really one of selection between the diverse types of "impossibility" situations discussed earlier. ${ }^{00}$ It does not appear to be helpful in the solution of the problem put by Hanbury, and it is somewhat surprising that he chooses to rely on Chitty despite subsequent analogies which seem more pertinent. ${ }^{21}$ Furthermore, the attempts to find the statute inapplicable appear the more unfortunate when one recognizes that Lord Cairns' Act was permissive rather than mandatory. The chancellor was authorized to award damages if in his discretion he chose to do so. Consideration of when, and on what basis, a chancellor should grant legal damages is indicated. We turn now to pursue that inquiry.

\section{QUASI-SCOUNDRELS AND THE UnConscionable Contract}

Chancellors subscribed to an ethical system which recognized a class of tainted agreements not so impure as to be voidable nor yet so pure as to merit specific performance. Thus, a vendee under a land contract suing for specific performance may find that despite the absence of such fraud as would render the contract unenforceable at law or subject to rescission in equity, the purchase price had been set so low that the chancellor would view enforcement as imposing a hardship on the defendant and deny specific relief. ${ }^{22}$ Plausible explanation abounded. The chancellor's remedy was "extraordinary." ${ }^{83}$ If his foot was not elastic, at least his "discretion" was sufficient to keep from helping quasi-scoundrels. A court of conscience would not enforce the unconscionable, although less sensitive law courts remained free, indeed obliged, to do so and the chancellor would not interfere. ${ }^{94}$

90. See p. 335 supra.

91. The Leeds case, supra note 79, while it concerned injunctive relief against tort seems to indicate that discretionary denial of such relief is no bar to application of Lord Cairns' Act. See 38 Harv. L. Rev. 667, 670 and n.15 (1925).

92. 5 CoRBIN, CoNTracts, $\$ \$ 1167,1168$ (1951) includes extensive citation of authorities.

93. The semantic approach to decision is not unamusing in this area. Alternate sets of familiar phrases are kept in readiness as, e.g.: "Specific performance is at most a matter of large and just discretion of the court. It is not a matter of strict right to a plaintiff. - . . It is an extraordinary remedy." N.Y. Brokerage Co. v. Wharton, 143 Iowa $61,69,119$ N.W. 969, 972 (1909). "Specific performance is not a mere matter of grace on the part of the chancellor. It is a matter of right in a proper case." Kurtz v. Gramenz, 198 Iowa 222, 232, 198 N.W. 325, 329- (1924).

Occasionally an added flourish serves for emphasis: "When, as in this case, the material facts are established by undisputed evidence, 'the principles of equity come into operation and pronounce with certainty and absoluteness whether the remedy shall be granted or withheld.'" J.I. Case Threshing Machine Co. v. Farnsworth, 28 S.D. 432, 442, 134 N.W. 819,822 (1912).

94. 5 CoRbin, Contracts 726-727 (1951) and cases discussed infra in this section. 
In this not uncommon situation shall equity leave the parties to their remedy at law or, in the interest of avoiding a multiplicity of suits, shall the chancellor invoke the clean-up rule and grant plaintiff the measure of damages to which the substantive law entitles him? The cases are divided. They say (1) yes (2) no and (3) maybe.

In Gabrielson v. Hogan ${ }^{95}$ specific performance was denied the vendor because the purchase price was one-third above fair value and other aspects of the negotiations tainted plaintiff's case. The lower court dismissed the suit. On appeal this was held error. The circuit court upheld the trial judge on the "principal question," ${ }^{86}$ of denying equitable relief. The opinion is little short of sermonic in disapproving inequity and in refusing to allow "the court to become the instrument of iniquity." ${ }^{97}$ However, appellant's contention that the lower court erred in not disposing of the entire controversy was upheld. A breach of contract had occurred and the measure of damages which would be applied at law is quite correctly stated as the difference between contract price and market price. Accordingly the court saw "no escape from the conclusion" that plaintiff was entitled to judgment. To follow the court's decision in this type of factual situation would be to grant plaintiff damages directly. proportioned to the hardship inherent in his original contract. Patently, the greater the hardship on defendant because he had agreed to too high a sales figure, ${ }^{98}$ the greater plaintiff's measure of damages. The result borders on the absurd.

Morgan $v$. Dibble ${ }^{99}$ represents an attempt to award damages in the situation under discussion without being ridiculous in the attempt. Specific performance was denied in the lower court solely because excessive price rendered the contract inequitable, ${ }^{100}$ but damages were

95. 298 Fed. 722 (8th Cir. 1924).

96. Id. at 724 .

97. Id. at 724-725.

98. The disparity between price and value figured significantly in the decision on denying equitable relief. Id. at 726.

Corbin appears to explain the Gabrielson case, supra note 95, on the ground that both parties had submitted the case to equitable jurisdiction. 5 CoRBIN, CoNTrActs 697-698 n.4 (1951). The opinion does use similiar language, $298 \mathrm{Fed}$. at 726, but in context the statement does not appear to be an attempt to place the decision on the ground of waiver of jury trial. The court cites other clean-up cases, emphasizes the "duty" to dispose of the entire controversy, and to grant "legal" relief where that be necessary. It should especially be noted that at the trial level the court dismissed suit because it should have been brought at law. Id. at 724. The "submission" on the part of the defendant was by way of a counterclaim (also dismissed). Statements that equity jurisdiction was at no time challenged seem little more than makeweights since the suit was for specific performance, and the trial court purposed to consider nothing beyond equitable relief. It seems clear that the court viewed the case, as it was obliged to do, as a clean-up problem.

99. 43 Cal. App. 116, 184 Pac. 704 (1919).

100. The appellate court points out a fatally inconsistent finding that the consideration was just and reasonable. The finding mentioned in the text, however, appears to have controlled the judgment below. 
limited to the cost of a certificate of title and to brokerage commissions. The appellate court compiled a roster of errors and reversed. Among other things, the measure of damages applied below was criticized for departing from the applicable statute, which provided, in effect, for recovery of full profit measured by the contract price. ${ }^{101}$ Small wonder that application of the clean-up doctrine was also found improper.

It might be argued that the defect is inherent in the substantive law and that inasmuch as the substantive law entitled plaintiff to the particular recovery allowed there is no point to loading dockets and fostering delay by requiring a new trial. On the other hand it can probably be asserted with some degree of confidence that were the case to be tried at law the jury might well be expected to make an adjustment in plaintiff's recovery which would reflect not so much the difference between the market price and contract price as other notions of the general equities between the parties. This is true even when neither of the parties has been guilty of bad faith. Cardozo recognized this when he wrote: "A contract is made without fraud or oppression. Change of circumstances brings hardship. The chancellor withholds his remedies, and remits the suitor to a claim for damages which is known to be futile." 102 It is this type of realism which is constantly in a trial lawyer's choice of forum as between law and equity even today. For the chancellor to find the difference between contract price and market price so great as to deny specific performance and yet so small as to allow plaintiff comparatively little recovery is well nigh impossible. ${ }^{103}$ The jury has no such limitation on its abilities. Indeed

101. Calif. Crv. Code $\$ 3307$ (Deering, 1949). The section was enacted in 1872. Royer v. Carter, 233 P.2d 539 (Cal. 1951), held that recovery of added expenses of resale may be had in addition to profits as measured by the code section, repudiating the language of Morgan v. Dibble on this point. Cf. Fawley case, note 105 infra.

Morgan v. Dibble has come in for some recent questioning. Some criticism, such as Bank of America v. Moore, 18 Cal.App.2d 522, 64 P.2d 460 (1937), has failed to distinguish between retaining a case for damages, as a legal cause with right to jury trial, and equity's jurisdiction to grant clean-up damages. Baran v. Goldberg, 86 Cal.App.2d 506, 194 P.2d 765 (1948), does make the distinction. The case involved too low a purchase price and damages were refused both in equity and at law. The court finds that plaintiff, in his desire to prove the price had been and yet remained equitable, had neither alleged nor proved normal contract damages. Further, when plaintiff desired a new trial to introduce newly discovered evidence to show legal damages, the evidence was held to be not newly discovered.

102. The Paradoxes of Legal Science 41 (1928). With regard to the number of triers of the fact OSBORN, THE MIND OF THE JUROR 63 (1937) suggests in another context that "With twelve members instead of six there are twice as many who may be governed by prejudice or by sympathy." $A$ fortiori, one chancellor compared to twelve jurors?

103. It has been argued that evidence introduced to show a contract inequitable should support an award for damages against the proponent of the evidence. In Englestein v. Shammo, 296 I11. App. 162, 15 N.E.2d 939 (1938), vendor introduced evidence that the property was worth $\$ 2600$ over the $\$ 7400$ contract price in his attempt to show the agreement inequitable. Purchaser, denied specific performance on other grounds, claimed that the above evidence was sufficient basis for a judgment for damages. The appellate court refused to adopt this reasoning on the ground that 
our dual system of courts imposes no such obligation upon it; once a judge had determined that no specific relief would be granted, the jury would later in another case make a single independent determination of the amount of the damages. That two triers of the fact arrived at substantially different findings is neither novel nor disturbing. Even under the most flexible of modern procedures where the two steps might occur in a single trial before one chancellor-judge, the salutary effect of the jury would not be vitiated; at law the judge's control is insufficient to render nugatory the laymen's unwritten code of damages. ${ }^{104}$

Finally, it is highly likely that a plaintiff, left to an action at law, might well be more amenable to the possibility of a fair compromise. The delay and expense inherent in further quest of a doubtful verdict are very persuasive. This appears true, although perhaps to a somewhat lesser degree, of remand for a second trial without dismissal of the action, as would be the case under many codes.

These factors make understandable the cases which refuse to allow assessment of damages where specific performance of an unconscionable bargain is denied. The oft-repeated formula runs to the effect that equity "will not lend its aid to enforce a contract which is in any respect unfair or savors of oppression, but in such cases will leave the party to his remedy at law." 105 Nothing clearer could be asked; the

vendor had introduced the evidence for a different purpose. While this portion of the opinion is indicative of an attempt to avoid the absurdity of the Gabrielson case, it appears of little significance because the court held that there was no contract and affirmed a decree ordering cancellation of the instruments.

In the Gabrielson case the court does open the door for a showing by either party that the market value at the time of breach had changed from what it was at the time of the contract. If such a change had occurred, however, it would appear to have been relevant on the issue of fairness and no evidence of same is mentioned. Indeed, the appellate court fixes the amount of the judgment to be entered in the absence of new evidence.

104. Effective control would require direction of a verdict in favor of the proponent of the evidence (plaintiff) in the presence of conflicting testimony as to value. This, it is generally conceded, the judge will not do. 9 WrgMore, EvIDENCE 306 (3d ed. 1940). Of course, if defendant has himself introduced uncontradicted testimony establishing a substantial figure as minimal damages, a different situation is presented. This is one substantial reason why defendant may well prefer to have two separate trials even when the duty of decision is divided between judge and jury. See text infra at note 115. Award of a new trial may well be a possibility. This, however, is of tactical aid to the defendant in forcing a smaller settlement. Finally, the judge does not have the same incentive to act in opposition to the verdict as will usually be true in equity. See note 48 supra and Baran v. Goldberg, supra note 101.

105. Prince v. Lamb, 128 Cal. 120, 128-129, 60 Pac. 689, 692 (1900), quoting from an earlier case. Dunlop v. Wever, 209 Iowa 590, 228 N.W. 562 (1930) and Marks v. Gates, 154 Fed. 481 (9th Cir. 1907), are to the same effect. The Wever case (in which rescission as well as specific performance was denied) makes it clear that plaintiff was free to pursue the case further at law. The Lainb opinion, which denied not only specific performance but a request for an accounting, leaves some doubt on whether, without an accounting, plaintiff will ever be in a position to prove damages at law. Cf. Ludlum v. Buckingham, 39 N.J. Eq. 563 (1885), where specific performance was impossible but damages were denied because of inequity. 
chancellor will lend no aid, hence damages are excluded. Affirmatively, he will leave the unfair plaintiff to law, indicating the need for another suit, or at best, another trial. The difficulty with this reasoning is that it proves too much. To say that defendant should have a jury assess his damages or that the chancellor will not negate his own decision seems reasonable enough. To say that he will lend "no aid," or will leave plaintiff to an action at law covers situations where other factors are involved. Thus a purchaser who has, by "inequity," arranged too low a contract price may, once specific performance is refused, prefer to recover his down payment and have done. If no difficult factual issues are present, no reasonable value of possession by purchaser to be evaluated for example, why should not the case be cleaned up and the litigation terminated? ${ }^{100}$ Further burdens on the legal system and delay in adjudication of just claims are hardly to be used as punishment for people who have soiled their hands.

An alternative and not uncommon formulation is subject to the same defects, without any advantage of clarity: After recognizing that "an action to recover damages in lieu of specific performance" lies in equity, a number of cases then add that "such damages depend upon the right to specific performance, and [are] not available until the latter is established". ${ }^{107}$ Since damages in equity in lieu of specific performance arise only when plaintiff cannot get specific performance, the rule seems to be that he can never get damages. The implication, however, is that plaintiff may have an "unenforceable right" to specific performance. Unfortunately, just when one views the right as

Cf. Nicholson v. Fawley, 112 Kan. 124, 210 Pac. 482 (1922), where plaintiff was denied specific performance because of a "mistaken mental mathematical calculation" by defendant which went to price. Reliance damages, including an agent's commission, were allowed plaintiff-vendor by way of clean-up. Cf. Buckley v. Patterson, 39 Minn. 250, 39 N.W. 490 (1888).

106. For an interesting, but abortive attempt to deny plaintiff any relief on a literal reading of "leave him to his remedy at law," see Slater v. Edgley, 328 Mich. 589, 44 N.W.2d 145 (1950).

It might conceivably be argued that dismissal with the possible running of the statute of limitations is a logical step where the chancellor desires to "lend no aid." This' seems too extreme where the judge has found no basis for rescission of the contract. Likewise, where the running of the statute is not involved (as in the New York statute considered supra note 16), so long as the plaintiff's particular measure of inequity is insufficient for the substantive law to bar him from all remedy, the burden of starting a new suit, getting service on defendant, and then waiting out the dockets seems an inappropriate means of either deterrence or retributive justice. For one thing the penalties are too haphazard, too unpredictable, depending in large measure for their efficacy on individual situations and circumstances. Further, to the extent that they add a burden to the judicial machinery, they penalize taxpayers and other litigants.

107. Eagle Oil \& Refining Co. v. James, 52 Cal.App.2d 669, 678, 126 P.2d 880, 884 (1942). The exact language has been included in California cases for some twenty-five years and draws on similar statements made fifty years before that. See authorities quoted ibid. and Baran v. Goldberg, supra note 101. 
established, but unenforceable, and when one views it as unestablished -and why-is not made clear.

An intermediate position leaves the matter of assessment of damages entirely in the discretion of the trial court. The facts of Banaghan v. Malaney ${ }^{108}$ are particularly striking. Specific performance against a widow was refused because plaintiff-purchaser "took an inequitable advantage" primarily with reference to price. On appeal plaintiff contended that his bill should have been retained for assessment of damages. This contention was rejected. The court mentioned the fact that damages had not been requested below, but emphasized that retention of the case was discretionary with the trial judge.

Despite the fact that such discretion in the trial court is subject to appellate review, ${ }^{109}$ the formula appears to have served as an inducement to decision without articulation of the practical considerations involved. This is of particular concern because the opinions in this country, as their forebearers in England, evidence a lack of careful discrimination between diverse factual situations. Cases in which equitable relief is denied, albeit for reasons which may range from impossibility to indefiniteness, are frequently lumped together in a single category for statement of the rule with respect to clean-up. Citations are chosen from this fictitiously fungible mass and language and precedents remain to bedevil bench and bar concerned with the workings of our fused system. Thus in Banaghan $v$. Malaney where judgment for contract damages ${ }^{110}$ would have effectuated the precise inequity which the chancellor sought to avoid, the court said on appeal that the chancellor might have awarded damages, adding, "Presumably it would have been done here, if the plaintiff had so requested". For authority that it might have been done the court cites a case ${ }^{111}$ where specific performance was denied because a conveyance according to the terms of the contract was impossible. Much to the same effect, a dictum in a later case, ${ }^{112}$ although specifically directed to the possibility of clean-up where equitable relief is denied because of overreaching or great hardship, is based on cases presenting factual situations which have nothing of the problems basic to the "inequity" cases. ${ }^{113}$ On the other hand, it should probably be pointed out that

108. 200 Mass. 46, 85 N.E. 839 (1908). Accord, Florimond Realty Co. v. Wayne, 268 Mass. 475, 167 N.E. 635 (1929).

109. Notes to Rule 17, 16 MASS. L.Q. No. 5,55 (1931).

110. Massachusetts grants loss of bargain damages on breach by the vendor without regard to "bad faith." MCCoRMICK, DAMAGES \& 177 (1935).

111. Rosenberg v. Heffernan, 197 Mass. 151,83 N.E. 316 (1908).

112. Nickerson v. Bridges, 216 Mass. 416, 421, 103 N.E. 939, 941 (1914).

113. Cited are Seton v. Slade, 7 Ves. Jr. 264, 32 Eng. Rep. 108 (1802), in which specific performance was decreed, but reference was ordered to determine whether vendor could make a good title, and American Stay Co. v. Delancey, 211 Mass. 229, 
in an area where factual situations are frequently not subjected to discriminating analysis and differentiation, a wide discretion in the trial court may prove a reasonably efficient device to prevent inequitable use of the clean-up rule.

Where the chancellor rejects a request for specific performance and further determines that a jury should determine the amount of damages it might seem that a second trial is inevitable. Perhaps it need not be. Let us instance a case. Suit is begun today for specific performance of an agreement of sale. It is resisted on the grounds that the contract is unconscionable. Let us assume that all involved recognize damages in lieu of specific performance to be unavailable in equity, yet plaintiff seeks damages as an alternative remedy. ${ }^{114}$ Further, the pleadings reveal that a trial will be needed to determine whether in fact the terms were unfair. Does a modern, flexible procedure have anything to contribute at this juncture? It may. It is entirely possible that a pre-trial conference will indicate the probability of the need for a jury verdict after denial of equitable relief because of overreaching. A judge apprised of the likelihood in advance and aware that much of the evidence relating to inequity will concern market value and the extent to which it differs from contract price, may desire to avoid two trials. In that event it is within his discretion to have the case heard before a jury initially. ${ }^{115}$ Upon conclusion of the evidence the judge would rule on whether equitable relief will be granted. A negative finding on this issue would then allow for an immediate decision by the jury on the issue of damages, or, if necessary, further evidence on the damage issue merely to fill in any gaps in the proof.

97 N.E. 911 (1912). Plaintiff in the latter case was suing to enjoin defendant from revealing trade secrets. Equitable relief was denied for failure of proof on a legally sufficient ground, and for legal insufficiency on a ground which had been proved. Damages for breach of contract were then awarded.

114. At one time a matter of importance, plaintiff's claim for damages in the alternative or for general relief is gradually assuming less significance, although still litigated in the clean-up situation. Liberal provision for amendment helps. Prosser v. Schmidt, 118 Colo. 502, 197 P.2d 318 (1948). Cf. Strack v. Fed. Iand Bank of Spokane, 218 P.2d 1052 (Mont. 1950). See, generally, Clark, Code Pleading § 44 (2d ed. 1947).

Plaintiff may not choose to ask for damages. Campbell Soup Co. v. Wentz, 172 F.2d 80 (3d Cir. 1948). In that case specific performance of a contract for the sale of carrots was refused because of unconscionable contract provisions not directly related to price, provisions which "carried a good joke too far." A liquidated damages clause combined with a skyrocketing market to limit recovery at law to a very small fraction of the actual damages. Cf. DURFEE, CASES ON EQUITY 94 (1928), to the effect that the usual practice in hardship cases has been for the court to dismiss the bill without consideration of any other course. This appears to reflect counsel's choice of tactics.

115. Positing demand for jury trial, FED. R. Crv. P. 42(a) provides for the type of flexibility indicated. Cf. Iowa R. CIv. P. 185 which gives the court the power indicated "Unless some party objects, stating that he will be prejudiced thereby." 
There is, no doubt, a potential loss of efficiency in the selection of a jury which may ultimately have no issue to decide. This, however, can be viewed as an insurance premium against the possibility of going through much of the evidence twice. At what point the premium appears excessive in terms of the potential saving is a matter best left to the discretion of the trial or pretrial judge. The relative quantity and complexity of the proof, the cost of the expert witnesses if any, the inconvenience of sending the jury out during testimony unrelated to damages will all figure in the decision. ${ }^{116}$

A further problem remains in connection with the contract tainted by quasi-fraud or inequity. A chancellor who refuses to award either specific performance or loss-of-bargain damages may still be asked, if our unconscionable plaintiff be a purchaser, to decree return of the down payment. If one is prepared to take at face value some of the lofty moral language already referred to ${ }^{117}$ the chancellor will "lend no aid," remitting a dull-conscienced plaintiff to law. On the other hand a plaintiff unsuccessful at specific performance and aware of the exigencies of jury trial may well prefer to have done with the entire sordid business and terminate the litigation ${ }^{118}$ if he could but recoup his down payment. Should he be forced, however, to enter on further proceedings which turning to law will usually require ${ }^{119}$ there would have been little reason for him to refrain from requesting full expectation damages. ${ }^{120}$ Hence clean-up may, over the broad run of cases, operate to limit recovery as well as litigation. The ethics of a procedural rule designed to discourage a litigant from obtaining the full measure of relief to which the substantive law declares him entitled may be held suspect. ${ }^{121}$ Yet it should not be forgotten that the basic rule of law which gives rise to the instant procedural problem is born of the chancellors' decision that a transaction could be tainted short of

116. The court may, of course, take cognizance of the fact that a defendant-purchaser who claims inequity may want to show very low market value in order to avoid specific performance and much higher market value on the legal issue to minimize damages. Plaintiff-vendor may likewise desire to maintain conflicting positions. See notes 104 and 114 supra.

117. See supra pp. 342-3.

118. Restitutionary recovery will preclude damages. See 5 Corbin, Contracts $\S 1223$ (1951).

119. Even if equity grant restitution, reference to a master may still be required to determine such questions of fact as, e.g., reasonable rental value.

120. A question of strategy may be involved. Fear of prejudicing the jury on any questions of fact on the restitutionary issue may militate against too high a demand. It is analogous to the practice of some attorneys not to litigate scope of employment in a negligence case on the theory that the chances of winning are negligible and the possible prejudicing of the jury on the questions of negligence and damages substantial. Whether one concurs with this analysis is not here of prime significance.

121. But cf. the quotation from Cardozo at note 102 sicpra. The quotation concludes: "Justice again is done by making charity a duty." 
poisoning, crippled but still alive. Enough evil is found present to require elimination of one of the alternative remedies normally available, but no more. The contract lives on; it will not be voided. In short, the substantive rule of law allowing loss-of-bargain damages at law, or the rule denying specific performance in equity may need reappraisal. What juries are in fact deciding, the extent to which interested parties abandon rather than litigate these claims, what kind of settlements are effected-these would certainly be important in such an inquiry. However, accepting the rule as it appears to be, termination of the litigation by return of plaintiff's down payment seems desirable.

Stearns $v$. Beckham ${ }^{122}$ presents the problem in an interesting procedural context. Suit for rescission of a contract for the sale of land was brought by vendor. The court found no basis for setting aside the contract, despite the inequity alleged and proved, and denied relief. ${ }^{123}$ Enough had been shown, however, to convince the court that the sharp dealing purchasers would have been denied specific performance. The trouble was that purchasers already in possession were not seeking specific performance. Invoking a bit of creative jurisprudence, the court set aside the deed and ordered purchasers to surrender the land to vendors unless within ninety days they, the purchasers, would sue for specific performance. ${ }^{124}$ Now the stage was properly set for the typically "neutral" situation in which equity would do nothing. All proceeded according to script. The purchasers filed a bill for specific relief which was denied, without prejudice, however, to further "suit or action on the contract". The basis for denial of specific performance was the precise ground held insufficient as a basis for rescission.

At this juncture purchasers urged a decree returning to them what they had paid in, a request resisted with vigor by vendors. ${ }^{125}$ The opinion discusses the clean-up problem at length in terms of the precedents and with an eye on the practicalities. It points out that dismissal and relegation to law would deny purchasers all relief because the statute of limitations had run. Return of the purchase money was ordered-and in a manner which demonstrates that no true clean-up problem was really involved. Despite the extended verbiage, the court finally found purchaser's down payment to be secured by a vendee's lien. Certainly enforcement of equitable liens involves equity juris-

122. 31 Gratt. 379 (Va. 1879).

123. Id. at 430 .

124. Id. at 380 .

125. Id. at 424-425. Cf. Buckley v. Patterson, 39 Minn. 250, 39 N.W. 490 (1888), where specific performance was denied on the grounds of mistake, but plaintiff purchaser was allowed recovery of his down payment as a minimum. 
diction in the classic sense. ${ }^{126}$ 'However, even in jurisdictions which will not recognize a vendee's lien, the question may fairly be put whether we do not have here, in effect, a demand for restitution by vendee, whose higher sense of business ethics has been found wanting. There seems to be no basis for holding that a decree ordering restitution in this circumstance is jurisdictionally outside the competence of an equity court. If historical perspective be not narrowed too far it would seem that there is no basis here for support of a constitutional claim of trial by jury. ${ }^{127}$ Likewise, efficiency and expediency would seem to militate in favor of rapid disposition, with reference to a master should additional facts remain to be found. ${ }^{128}$

\section{Making Good Law for Hard Cases}

Many of the cases discussed earlier are referred to as "hardship" cases, the hardship resulting from the fraud which taints them. Another type of hardship case may be as different in kind as it is similar in categoric heading. ${ }^{129}$ Such are cases in which specific performance would be oppressive, but damages, in full legal measure, would not be. Untainted by fraud, they arise in situations where no hardship inhered in the agreement itself, but rather developed out of some subsequent event or occurrence. Typical is the case of City of London $v$.

126. Purchasers liens enforceable in equity are considered in 1 GLENN, Mortgages 74 (1943). See also Lewis, Damages Given in Equity in Lien of a Specific Performance, 50 AM. L. REg. 394, 405 (1902). Cf. Slater v. Edgley, 328 Mich. 589, 44 N.W.2d 145 (1950).

127. U.S. v. Cowen's Estate, 91 F. Supp. 331 (D. Mass. 1950) held that there existed no right to jury trial in a suit for restitution alone on the ground that "The traditional equity power of the court is invoked in the prayer for an order of restitution. . ." Id. at 332. Accord, Creedon v. Randolph, 165 F.2d 918 (5th Cir. 1948). See 5 Moore, Federal Practice 188-190 (2d ed. 1951). The cases build on Porter v. Warner Holding Co., 328 U.S. 395 (1946) which holds restitution to be an equitable remedy, but which does so for the purpose of clean-up in an injunction suit where the injunction was granted. Furthermore, the Porter case, by way of dictum, states specifically that restitutionary "recovery could not be obtained through an independent suit in equity if an adequate legal remedy were available." Id. at 399 . See United States v. Moore, 340 U.S. 616 (1951), where the issue was avoided because of no timely demand for jury trial. Even if Cowen's Estate and Creedor would be insufficient authority to support an independent suit in equity for return of the down payment on a land contract, there does seem to be sufficient basis for positing equitable jurisdiction to terminate the litigation by way of restitution where suit has been brought for specific performance and it is denied.

The question of restitution in equity is thus divided into three situations: (1) where other equitable relief is granted; (2) where other equitable relief is asked but not granted; and (3) where no other equitable relief is even requested. Our problem is the second situation. $C f$. the situation where a contract for the sale of land is unenforceable because of the statute of frauds. "If the buyer should bring a bill in equity for specific performance the court of equity would decree repayment in his favor even though it denied specific enforcement." 2 CoRBIN, CoNTracts 163-164 (1951).

128. Where purchaser has been in possession, as in the Stearns case, reasonable value of his possession as well as any negligent damage to the property need assessment. 31 Gratt. 379, 431-432 (Va. 1879).

129. For an illuminating discussion of the terminology see 5 CorbiN, Contracts $702(1951)$. 
Nash. ${ }^{130}$ The court there found that very extensive repairs made by defendant lessee had not discharged lessee's contractual obligation to build new houses. Nevertheless, Lord Hardwicke denied specific performance on the ground that it would have involved too great a hardship on defendant who had invested $£ 2200$ in the rebuilding. To require the defendant to tear down the repaired buildings and replace them with new ones would have placed upon him an onerous burden without concomitant public good. Hence, the court was obliged to decide whether relief by way of damages should be granted in the same action. Here, obviously, the granting of full compensation to lessor would eliminate any objection of hardship which might be claimed by lessee as against specific performance. The primary question presented for decision was whether equity had jurisdiction to retain the suit. Lord Hardwicke was in a sense able to avoid direct resolution of this issue. He upheld continued equity jurisdiction on the tenuous ground of multiplicity of suits after having found that, aside from the trial at law which was in question, an earlier assignment might result in a single additional action. That accomplished, he directed an issue to be tried before a jury. More recently the problem has been met squarely and the power of a court of equity to award damages upheld. ${ }^{131}$

There are hardship cases which do not involve overreaching or imposition in the making of the original agreement, but which, nevertheless, are not readily disposed of by granting money damages in lieu of specific relief. Thus in Willard $v$. Tayloe ${ }^{132}$ Congressional legislation declaring greenbacks to be legal tender despite their inferior value compared to coin presented such a change in circumstances as to make specific enforcements or legal damages equally oppressive. Use by the court of such familiar phrases as "leave the parties to their remedy at law" 183 is readily understandable, although the decision in that case was to grant specific relief conditioned on tender of gold coin.

Finally, changed circumstances may present other policies unrelated to the financial loss involved in either damages or specific performance. Thus in Wentworth $v$. Manhattan Market $\mathrm{Co}^{134}$ the court denied specific relief of a contract by lessee to erect a building because "it would be inequitable to compel [defendant] to erect a building for which it has no use under changed conditions." ${ }^{135}$ Despite the label of inequity, the primary operative factor in the decision seems the

130. 3 Atk. 512, 26 Eng. Rep. 1095 (1747).

131. Sanitary District v. Martin, 227 I11. 260, 81 N.E. 417 (1907).

132. 8 Wall. 557 (U.S. 1869).

133. Id. at 567. Cf. Hart v. Brown, 6 Misc. 238, 27 N.Y. Supp. 74 (1893).

134. 216 Mass. 374,103 N.E. 1105 (1914).

135. Id. at 380,103 N.E. at 1108. 
potential social waste. Plaintiff's right to the building at the end of the term entitled him to substantial damages, and it is not clear that defendant would save any actual cash by award of a money judgment. The court did not hesitate to have damages assessed in equity in an effort to terminate the litigation.

\section{Caveat and Conclusion}

A simple, readily applied, distillation of what equity courts have been doing with the clean-up problem is a useful tool in determining the right to jury trial. The objection to a number which have been proposed ${ }^{136}$ is that they do not seem to work throughout the spectrum of situations. ${ }^{137}$ Good faith alone will not explain the result in cases of ensuing hardship caused by changed circumstances out of the control of both parties. ${ }^{138}$ Denial of clean-up to a party where his own conduct has made the equitable relief unavailable will not cover the man who repaired instead of rebuilding. ${ }^{139}$ Denial of specific performance because of the terms of the contract ${ }^{140}$ is inadequate to explain award of damages where indefiniteness or difficulty of supervision has been the basis for refusing the chancellor's remedy. ${ }^{141}$

136. 5 WIIIISTON, CoNTracts 4036 (Rev. ed. 1937) states the general rule to be that damages will be awarded where specific relief is unsuitable or inequitable unless plaintiff knew or should have known specific relief would not be granted. This leads him to cite with approval both Gabrielson v. Hogan, supra note 95, and Banaghan v. Malaney, supra note 108, the former under the first half of his rule, the latter under the qualifying clause. It is submitted that Williston is attempting unsuccessfuily to apply the rule governing clean-up where specific performance is impossible, presented earlier in the same section. Id. at $4035, \S 1444$.

While Williston talks the law-equity dichotomy, he cites REstatenent, ConTRACTs $\$ 363$ (1932), as in accord. That section, however, does not deal with right to jury trial. The Restatement is careful to emphasize the point. Williston, on the other hand, makes no such reservation and his analysis is clearly in terms of the cleanup problem.

137. 5 Moore, Federal Practice 170 (2d ed. 1951) states there is no right to jury trial for damages in lieu of specific performance where "there was a basis for equity jurisdiction but the chancellor in the exercise of a sound discretion declines to decree performance." If it be intended to cover the spectrum, it would reaffirm the Gabrielson case, supra note 95 . Is there any less "basis" for equitable relief there than in a hardship case such as Nash, supra note 130? Cf. text at note 107 supra.

138. See text at notes $132-133$ supra.

139. 5 CORBIN, CoNTrActs 696-697 (1951).

140. Id. at 697 . Corbin, however, is careful to qualify his proposals, e.g., "will seldom be retained." He also warns against "any mechanical form of statement" and speaks of best serving "private justice and public convenience."

141. Gulbenkian v. Gulbenkian, 147 F.2d 173 (2d Cir. 1945), is a leading case affirming clean-up under the Federal Rules where specific relief was denied because of indefiniteness. The contract there included such terms as "in such manner as may be determined," if "said counsel deem it advisable." Riverside Iand \& Irrigation Co. v. Sawyer, 24 Colo. App. 442, 134 Pac. 1011 (1913) reached the same result by reasoning which may be questioned.

Difficulty of supervision: McCormick v. Proprietors of Cemetery of Mt. Auburn, 285 Mass. 548, 189 N.E. 585 (1934) ; Bank of America v. Moore, 18 Cal.App.2d 522, 64 P.2d 460 (1937) (But see comment on the latter case in note 101 supra); Queens Plaza Amusements, Inc. v. Queens Bridge Realty Corp., 265 App. Div. 1057, 39 
The opinions do not reveal any such nice distinctions in factual situations, but tend rather to talk in broad terms of clean-up generally, bolstering conclusions with indiscriminate citations. Yet the holdings do appear to reveal a pattern of equity behavior which seems to recognize the availability of a clean-up rule wherever the award of damages will not perpetrate the very injustice which denial of specific performance is intended to prevent. Thus stated, and limited to the area of "discretionary" denial of specific performance, it would seem a reasonable basis for a contemporary clean-up rule.

Neatly to state a rule is not yet to demonstrate ease in application. To determine whether or not money damages will, or will not, perpetrate the hardship or inequity which has become the chancellor's concern may answer the clean-up question in many situations. It is not, however, infallibly litmuslike. Instance the situation presented by Miller v. Fulmer ${ }^{142}$ in which sufficient fraud inhered in the agreement of sale to prevent specific performance, but the deceit was neither directed to nor reflected in the purchase price. In this respect the case differed from the quasi-fraud cases earlier considered. An agent for an undisclosed principal had induced a competitor to enter into a contract for the sale of land by false promises concerning the use to which the land would be put. Competitor was denied rescission on the ground that a promise is not a deceitful representation. ${ }^{143}$ Agent was denied specific performance because of his "bad faith, deceit and trickery". The litany is intoned: "Specific performance is not of right, but of grace. . . [equity] will leave the parties to their remedies at law." 144

Clean-up in this situation may involve three separate problems: (1) Recovery by the agent, as purchaser, of a down-payment and no more. This matter has already been sufficiently considered. (2) Recovery by the agent, as purchaser, of reliance damages, including such items as the cost of examining title. ${ }^{145}$ (3) Recovery by the agent, as purchaser, of expectation damages, or the benefit of his bargain. As

N.Y.S.2d 463 (2d Dept. 1943) allow clean-up. Accord: Columbus Club v. Simons, 110 Okla. 48, 236 Pac. 12 (1925) (impracticality of contract to lend money).

Some early cases such as Zeringue v. Texas \& P. Ry., 34 Fed. 239 (E.D. La. 1888) refused damages in equity where specific relief was denied because of indefiniteness and difficulty of supervision. Marked reluctance in those days to undertake any supervisory tasks may in part account for this attitude. Park v. Minn., St. P. \& S.S.M. Ry., 114 Wis. 347, 89 N.W. 532 (1902) denied clean-up, apparently, however, in the exercise of the chancellor's discretion.

142. $25 \mathrm{~Pa}$. Super. 106 (1904).

143. Was there a statement of present intention which would support a finding of actual fraud? See Prosser, TorTs 764 (1941). Even if the case be wrong on its facts, circumstances involving overreaching without a definitive promise or affirmation would present the same problem. Cf. Banaghan v. Malaney, sipra note 108. 144. $25 \mathrm{~Pa}$. Super. at 115 .

145. See McCormick, Damages \& 182 (1935). 
used in this context such benefit refers to so much of the market valuecontract price differential as is unrelated to the deceit. ${ }^{146}$ Appreciation of property values between the signing of the agreement and time of breach isolates this item in precise fashion.

Will the previously suggested test prove helpful in determining whether clean-up, if asked, should be granted ? ${ }^{147}$ Will the award of money damages "perpetrate the very injustice which denial of specific relief is intended to prevent"?

In a very narrow sense a negative answer may seem appropriate. The deceit was intended to obtain for the principal particular land for use in a particular manner. Denial of specific performance will prevent this. In a broader sense, however, we may recognize that award of reliance damages, and more particularly of the benefit of the bargain, may prove to be an economic lever which, if available cheaply and promptly in the same action, may in fact force the vendor specifically to perform. ${ }^{148}$ Possibility of rapid resale at the higher price, vendor's potential liability for yet another brokerage commission, these are details which may need consideration in the specific case. They need not detain us here. Suffice it to suggest that difficulty in determining what will now prevent (and in the future deter ${ }^{149}$ ) such inequity does not vitiate the essential validity of making the inquiry. In short, occasionally it may not be easy for the chancellor to determine how far he can go in awarding clean-up damages without enforcing in fact the inequity he condemns in words. He may even determine to deny clean-up because of a risk that the primary purpose will be frustrated. But this does not detract from the utility of the inquiry. Not even the chemist can run the gamut of qualitative analysis with tests as speedily performed and as easily evaluated as the use of litmus paper.

Perhaps the formulation suggested for damages in lieu of specific performance in the limited area considered will be helpful, with slight modifications, in dealing with other aspects of the clean-up rule. If valid, our orientation only suggests that the exploration be in the context of detailed examination of the practicalities involved.

A plethora of problems remain. Positing that clean-up is available so that defendant's right to jury trial may be defeated, is it ob-

146. A rise in market value as a result of the use actually contemplated, but objected to by vendor (e.g., conversion into a business district) would give rise to an added differential between contract price and market value at time of breach, but one related to the "deceit."

147. Supra p. 351.

148. The Pennsylvania cases refusing loss of bargain damages in land contracts unenforceable because of the statute of frauds point out that such recovery "would in effect be specifically enforcing the contract." Seidlek v. Bradley, $293 \mathrm{~Pa} .379,382,142$ At1. 914,915 (1928).

149. Cf. note 106 supra. 
ligatory on plaintiff, so that he no longer has a right to jury trial on the issue of damages? Phrased differently, may plaintiff join two "suits," the one in equity for specific relief, the other at law for damages to be tried only if the first is decided in his adversary's favor? Does this right to two-in-one turn on whether plaintiff may bring two successive suits, the first in equity and a later one at law? On whether at one time in the past he might have brought two? ${ }^{150}$ It is apparent at a glance, however, that the practicalities in favor of extension of res judicata in the second situation are not necessarily operative where but one suit has been brought and the true issue is mode of trial. We need not "set the clock back many years," ${ }^{151}$ nor set it forward either, by a decision on mode of contemporary trial. Intricate interplay of the rewards and limitations of historical study make the subject rich in potential It deserves separate treatment. Some has been given; more has been promised. ${ }^{152}$

That the union of law and equity has been a boon, despite the problems it has created, is established almost beyond cavil. ${ }^{153}$ We may some day restate the constitutional right to jury trial to avoid, or limit, the backward glance. Perhaps this may prove the next major advance in the quest for a more perfect union.

150. Shall the multiple-count plaintiff be charged with what the court terms "his own-preferred theory" of the case? This is the language used in 5 MOORE, FEDERAL Practice 180 (2d ed. 1951). Consider such cases as Gaumont v. Warner Bros. Pictures, 2 F.R.D. 45 (S.D.N.Y. 1941) ; Fraser v. Geist, 1 F.R.D. 267 (E.D. Pa. 1940); Bellavance v. Plastic-Craft-Novelty Co.; 30 F. Supp. 37 (D. Mass. 1939). Sklarsky v. A. \& P., 47 F.2d 662 (S.D.N.Y. 1931), a res judicata case, figures prominently in recent mode-of-trial decisions. Cf. Bruckman y. Hollzer, 152 F.2d 730 (9th Cir. 1946). See Morris, Jury Trials Uttder the Federal Fusion of Law and Equity, 20 TEX. L. REv. 427 (1942).

151. Cardozo, J. dissenting in City of Syracuse y. Hogan, 234 N.Y. 457, 465, 138 N.E. 406,409 (1923) where the issue was right to jury trial.

152. Kharas, A Century of Lau-Equity Mergex in New York, 1 Syracuse L. REv. 186, 196-197 n.63 (1949) notes that a colleague has projected an article to consider some of these problems. Some have been discussed in Pike and Fischer, Pleadings and Jury Rights in the New Federal Procedure, 88 U. of PA. L. REv. 645 (1940). Cf. 14 Mo. L. Rev. 161 (1949). (1945).

153. But cf. Emmerglick, $A$ Century of the Nere Equity, 23 TEx. L. Rev. 244 